\title{
Simultaneous bioremediation and biodetection of mercury ion through surface display of carboxylesterase E2 from Pseudomonas aeruginosa PA1
}

\author{
Kun Yin ${ }^{\text {a, }}$, Min Lv $^{\text {a }}$, Qiaoning Wang ${ }^{a}$, Yixuan $\mathrm{Wu}^{\mathrm{a}}$, Chunyang Liao ${ }^{\mathrm{b}, ~ *}$, Weiwei Zhang ${ }^{\mathrm{a}}$, \\ Lingxin Chen ${ }^{\text {a }}{ }^{* *}$ \\ a Laboratory of Coastal Environmental Processes and Ecological Remediation, The Research Center for Coastal Environmental Engineering and Technology, \\ Yantai Institute of Coastal Zone Research, Chinese Academy of Sciences, Yantai 264003, China \\ b State Key Laboratory of Environmental Chemistry and Ecotoxicology, Research Center for Eco-Environmental Sciences, Chinese Academy of Sciences, \\ Beijing 100085, China \\ ${ }^{\mathrm{c}}$ Graduate School of the Chinese Academy of Sciences, Beijing 100039, China
}

\section{A R T I C L E I N F O}

Article history:

Received 15 April 2016

Received in revised form

29 June 2016

Accepted 21 July 2016

Available online 26 July 2016

\section{Keywords:}

Carboxylesterase E2

Surface display

Mercury

Bioremediation

Biodetection

\begin{abstract}
A B S T R A C T
Mercury is a toxic heavy metal and presents significant threats to organisms and natural ecosystems. Recently, the mercury remediation as well as its detection by environmental-friendly biotechnology has received increasing attention. In this study, carboxylesterase E2 from mercury-resistant strain Pseudomonas aeruginosa PA1 has been successfully displayed on the outer membrane of Escherichia coli Top10 bacteria to simultaneously adsorb and detect mercury ion $\left(\mathrm{Hg}^{2+}\right)$. The transmission electron microscopy analysis shows that $\mathrm{Hg}^{2+}$ can be absorbed by carboxylesterase $\mathrm{E} 2$ and accumulated on the outer membrane of surface-displayed $E$. coli bacteria. The adsorption of $\mathrm{Hg}^{2+}$ followed a physicochemical, equilibrated and saturatable mechanism, which well fits the traditional Langmuir adsorption model. The surface-displayed system can be regenerated through regulating $\mathrm{pH}$ values. As its activity can be inhibited by $\mathrm{Hg}^{2+}$, carboxylesterase $\mathrm{E} 2$ has been used to detect the concentration of $\mathrm{Hg}^{2+}$ in water samples. The developed surface display system will be of great potential in the simultaneous bioremediation and biodetection of environmental mercury pollution.
\end{abstract}

๑) 2016 Elsevier Ltd. All rights reserved.

\section{Introduction}

Environmental pollution by heavy metals has been of public concern with the development of industry and expansion of population. Since the heavy metal pollution is non-reversible, once toxic heavy metals enter into the biosphere, they will have a long and profound effect on the environment and seriously threaten the health of organisms (Cheng, 2003; Järup, 2003; Zhao et al., 2011; Zhang et al., 2014). Mercury, as one of the most dangerous heavy metals, is very harmful to humans especially to pregnant women and fetuses (Dahahir et al., 1973; Harada, 1995; Bakir et al., 2012; Park and Zheng, 2012). Once entering into the body, mercury ion $\left(\mathrm{Hg}^{2+}\right)$ can cause toxic effects to a variety of target organs,

\footnotetext{
* Corresponding author.

** Corresponding author.

E-mail addresses: cyliao@rcees.ac.cn (C. Liao), lxchen@yic.ac.cn (L. Chen)
}

especially to kidneys where inorganic mercury is firstly taken up and accumulated (Zalups, 2000; Pal and Ghosh, 2012). Mercury ion can bind to DNA and inhibit transcription factors (Rodgers et al., 2001; Cardenas et al., 2015). It can also induce mitochondrial dysfunction, which further results in oxidative stress and lipid peroxidation (Lund et al., 1991; Meyer et al., 2013). As the consequence, mercury poisoning can induce various diseases such as hypertension, cardiovascular disease, stroke and immune dysfunction (Houston, 2011). Because of its special physicochemical characteristics, mercury has been widely used in various industrial products such as batteries, fluorescent lamps, electronic switches, thermometers, barometers, manometers, mercury relays, and other devices, resulting in the continuous emission of $\mathrm{Hg}^{2+}$ into the environment. In some seriously polluted area, elevated levels of $\mathrm{Hg}^{2+}$ were found in water $(\mu \mathrm{g} / \mathrm{L})$ and sediment $(\mathrm{mg} / \mathrm{kg}$ ) (Jiang et al., 2006).

To date, various methods have been developed to remediate or detect mercury pollution. Traditional mercury remediation 
technologies focus on physical or chemical methods such as removing $\mathrm{Hg}^{2+}$ by alumina, zeolite, molecular sieves and sulfur. These techniques are usually cost-expensive and easily generate hazardous byproducts (Shafawi et al., 2000; Jurng et al., 2002). The detection of $\mathrm{Hg}^{2+}$ is usually achieved by inductively coupled plasma-mass spectrometry (ICP-MS) and atomic fluorescence spectrophotometer (AFS), but such instrumental analyses are complicated, costly and time-consuming (Moreno et al., 2010; Zhang et al., 2010). Given the widespread occurrence and high toxicity of $\mathrm{Hg}^{2+}$, new techniques allowing simultaneous mitigation and detection of $\mathrm{Hg}^{2+}$ pollution in the environment are useful and should be explored.

It is known that bioremediation technologies present advantages, including environmental friendliness, good performance and low cost (Bulgariu and Bulgariu, 2012; Mudhoo et al., 2012; Sheng et al., 2013). Over the last few decades, development of biotechnology provides many novel strategies for remediation of heavy metal pollution by utilizing algae, fungi and bacteria. Among them, surface display of specific proteins on microbes for the biosorption of heavy metal ions has emerged as a new research hotspot ( $\mathrm{Wu}$ et al., 2008; Saleem et al., 2008; Biondo et al., 2012). Further, the surface display technique can be employed to establish simple biosensors for detection of contaminants including heavy metals (Lee et al., 2003; Liu et al., 2013; Wei et al., 2014). The earlier study shows that mercury-resistant strain Pseudomonas aeruginosa owns excellent mercury adsorption capacity (Chang and Hong, 1994). Our previous study illustrates that the carboxylesterase E2 from Pseudomonas aeruginosa PA1 can well adsorb $\mathrm{Hg}^{2+}$ (Yin et al., 2014). Additionally, the activity of carboxylesterase E2 is inhibited by $\mathrm{Hg}^{2+}$, which can be utilized for measurement of $\mathrm{Hg}^{2+}$. Currently, there are few methods can concurrently remediate and detect $\mathrm{Hg}^{2+}$. Therefore, the objective of this study is to develop a multifunctional surface display system by using carboxylesterase E2 from Pseudomonas aeruginosa PA1 to achieve simultaneous remediation and detection of $\mathrm{Hg}^{2+}$. The carboxylesterase $\mathrm{E} 2$ has been successfully inserted on the outer membrane of Escherichia coli (E. coli) bacterial cells, which obviously increases its adsorption capacity. The binding $\mathrm{Hg}^{2+}$ can be desorbed by regulating $\mathrm{pH}$ value and the system can be reused, which also avoid hazardous byproducts. The recombinant $E$. coli bacteria are endowed with an enhanced ability of reducing the biological toxicity of $\mathrm{Hg}^{2+}$ to plant growth. Additionally, the detection of $\mathrm{Hg}^{2+}$ by the surface-display system is successfully performed in various real water samples. Therefore, the property of surface-display system shows promise in the remediation and detection of $\mathrm{Hg}^{2+}$ in polluted areas.

\section{Materials and methods}

\subsection{Construction of surface display system}

The chromosomal DNA of Pseudomonas aeruginosa PA1 was firstly extracted. A 600-bp DNA fragment encoding carboxylesterase E2 was amplified with forward primer CEDF3 (5'-ATGAGCGAACCCCTGATCCTC- $\left.3^{\prime}\right)$ and reverse primer CEDR3 (5'GAGGCGCTTGCGCAGCC- $3^{\prime}$ ) from the chromosomal DNA. Then the gene fragment was treated with T4 polynucleotide kinase and inserted into the Scal site of pBAT1 (Liu et al., 2005). The obtained plasmid was transformed into the $E$. coli Top10 to construct the E. coli Top10/pBATE2 bacteria, which could display carboxylesterase E2 on its cell surface. The surface display system was verified by immunoassays, which was clearly described in the supplementary information. The bacteria culture conditions, plasmid stabilization and survival rate of E. coli Top10/pBATE2 bacteria was also described in the supplementary information.

\subsection{Bioadsorption of mercury ion by the surface display system}

The E. coli Top10, Top10/pBAT1 and Top10/pBATE2 strains were grown in LB medium (containing $100 \mu \mathrm{g} / \mathrm{mL}$ ampicillin for Top10/ pBAT1 and Top $10 / \mathrm{pBATE} 2$ ) at $37^{\circ} \mathrm{C}$ to $\mathrm{OD}_{600}=0.8-1$. The cells were washed by $0.1 \mathrm{M}$ PBS ( $\mathrm{pH}$ 7.0) for three times and lyophilized to measure the dry weight. Then the bacterial cells were resuspended by $0.1 \mathrm{M}$ PBS (pH 7.0) to $2.5 \mathrm{mg} / \mathrm{mL}$. For testing the adsorption of $\mathrm{Hg}^{2+}$, different concentrations of $\mathrm{Hg}^{2+}(0.1,0.5$ and $1 \mathrm{mM})$ were added to the above strain solution and incubated at $25{ }^{\circ} \mathrm{C}$ for $30 \mathrm{~min}$. After centrifugation $(12,000 \mathrm{rpm}, 5 \mathrm{~min})$, the supernatant was collected for analyzing the concentrations of $\mathrm{Hg}^{2+}$ by AFS. The effective adsorption rates of $\mathrm{Hg}^{2+}$ were calculated by $(1-\alpha) \times 100 \%$, where $\alpha$ meant the ratio of mercury concentration in solution after over before the adsorption by the bacteria cells.

To examine the adsorption selectivity of E. coli Top10/pBATE2 bacteria, $1 \mathrm{mM} \mathrm{Hg}^{2+}, \mathrm{Cu}^{2+}, \mathrm{Pb}^{2+}, \mathrm{Co}^{2+}, \mathrm{Cd}^{2+}$ and $\mathrm{Cr}^{3+}$ were added into the bacterial solutions and incubated at $25{ }^{\circ} \mathrm{C}$ for $30 \mathrm{~min}$, respectively. After centrifugation $(12,000 \mathrm{rpm}, 5 \mathrm{~min})$, the supernatant was collected and the metal ions were detected by the ICPMS $\left(\mathrm{Cu}^{2+}, \mathrm{Pb}^{2+}, \mathrm{Co}^{2+}, \mathrm{Cd}^{2+}\right.$ and $\left.\mathrm{Cr}^{3+}\right)$ and AFS $\left(\mathrm{Hg}^{2+}\right)$, respectively. To examine the influences of possible interference ions on the adsorption capacity of $\mathrm{Hg}^{2+}$ by E. coli Top10/pBATE2 bacteria, $1 \mathrm{mM}$ $\mathrm{Hg}^{2+}$ as well as $1 \mathrm{mM} \mathrm{Cu}{ }^{2+}, \mathrm{Pb}^{2+}, \mathrm{Co}^{2+}, \mathrm{Cd}^{2+}$ or $\mathrm{Cr}^{3+}$ were jointly added into the bacterial solutions and incubated at $25^{\circ} \mathrm{C}$ for $30 \mathrm{~min}$, respectively. To explore the equilibrium sorption isotherms of $\mathrm{Hg}^{2+}$ by the $E$. coli Top10/pBATE2 bacteria, $0.05,0.1,0.2,0.4,0.6,0.8,1,2$, $4,6,8$, and $10 \mathrm{mM} \mathrm{Hg}^{2+}$ were added into the bacterial solutions and incubated at $25^{\circ} \mathrm{C}$ for $30 \mathrm{~min}$, respectively. The $\mathrm{Hg}^{2+}$ concentration in bacterial solution was similarly analyzed as mentioned above. The transmission electron microscopy analysis and regeneration of the surface display system was described in the supplementary information.

\subsection{Detoxification of mercury in the culture of mung bean}

After washed and soaked in double distilled $\mathrm{H}_{2} \mathrm{O}$ at $25^{\circ} \mathrm{C}$ for $8 \mathrm{~h}$, the mung seeds were transferred onto the filter paper in Petri dishes (90 mm diameter). The mung seeds were cultured in dark with double distilled $\mathrm{H}_{2} \mathrm{O}$ alone or combination with $E$. coli Top10, E. coli Top10/pBATE2, and/or $\mathrm{Hg}^{2+}$ solution. All above-mentioned solutions including the $\mathrm{Hg}^{2+}$ solution were replaced daily. After five days of culture, the seedling lengths in dishes were measured for characterizing the effectiveness of $E$. coli Top10/pBATE2 for remediation of mercury.

\subsection{Detection of mercury ion by the surface display system}

For $\mathrm{Hg}^{2+}$ detection, the $E$. coli Top10/pBATE2 bacterial cells were cultured in LB medium with $20 \mu \mathrm{g} / \mathrm{mL}$ ampicillin to an $\mathrm{OD}_{600}$ of 0.8-1.0. The bacterial cells were washed three times by $0.1 \mathrm{mM}$ PBS buffer ( $\mathrm{pH} 7.0$ ) and adjusted to an $\mathrm{OD}_{600}$ of 1.0 (about $3.75 \times 10^{8}$ bacterial cells). $100 \mu \mathrm{L}$ bacterial solution was added to $900 \mu \mathrm{L}$ PBS buffer ( $\mathrm{pH}$ 7.0) containing different concentrations of $\mathrm{Hg}^{2+}$. After incubated at $25{ }^{\circ} \mathrm{C}$ for $10 \mathrm{~min}, 0.5 \mathrm{mM}$-nitrophenyl acetate was added to the solution and incubated at $25{ }^{\circ} \mathrm{C}$ for another $20 \mathrm{~min}$. The solution was then detected at $400 \mathrm{~nm}$ using a $\mu$-Quant microplate reader Nanodrop 2000C. To investigate the selectivity of Top10/pBATE2 cells for $\mathrm{Hg}^{2+}$, bacterial cells solution containing $0.1 \mathrm{mM} \mathrm{Hg}^{2+}$ as well as $1 \mathrm{mM} \mathrm{Na}{ }^{+}, \mathrm{K}^{+}, \mathrm{Cu}^{2+}, \mathrm{Mg}^{2+}, \mathrm{Co}^{2+}, \mathrm{Cd}^{2+}, \mathrm{Pb}^{2+}$ or $\mathrm{Cr}^{3+}$ were used. To measure the sensitivity of $E$. coli Top10/ pBATE2, various concentrations of $\mathrm{Hg}^{2+}(0,0.5,1,2,4,6,8,10,20$, $40,60,80,100,300,500,700$ and $1000 \mu \mathrm{M}$ ) were separately added to the bacterial solution under optimal conditions. The surface display system was applied for analyzing $\mathrm{Hg}^{2+}$ in spiked real water 
samples, as described in the supplementary information.

\section{Results and discussion}

\subsection{Design of the surface-display system}

Few methods can be used for simultaneous remediation and detection of $\mathrm{Hg}^{2+}$. Therefore, we expect to achieve this challenge by utilizing surface-display system and special bio-enzyme. The bioenzyme should own high adsorption capacity to $\mathrm{Hg}^{2+}$ and in the meanwhile the activity of such bio-enzyme should be sensitively inhibited in the presence of $\mathrm{Hg}^{2+}$. It is known that mercuryresistant strain Pseudomonas aeruginosa owns excellent mercury removal ability (Chang and Hong, 1994). The Pseudomonas aeruginosa PA1 has already been isolated in our previous work (Yin et al., 2014). As a bio-element secreted from Pseudomonas aeruginosa PA1, carboxylesterase $\mathrm{E} 2$ can also adsorb $\mathrm{Hg}^{2+}$ with satisfied adsorption capacity. After binding with $\mathrm{Hg}^{2+}$, the activity of carboxylesterase E2 is inhibited, which is suitable to be utilized to detect $\mathrm{Hg}^{2+}$. Therefore, carboxylesterase E2 is chosen to establish the surfacedisplay system to achieve simultaneous remediation and detection of $\mathrm{Hg}^{2+}$. As shown in Fig. 1, the carboxylesterase E2 from Pseudomonas aeruginosa PA1 was displayed on the surface of E. coli Top10 bacterial cells with assistance of plasmid pBAT1 (Zhang et al., 2013). In the surface display system, a $\beta$-domain of autotransporter inserts into the outer membrane, through which carboxylesterase E2 is translocated to the cell surface and exists as a membraneanchored protein. The $\mathrm{Hg}^{2+}$ can be immobilized on the outer membrane of $E$. coli bacteria with assistance of surface-displayed carboxylesterase E2 and thus the mercury polluted water is remediated through removal of $\mathrm{Hg}^{2+}$. Carboxylesterase E2 can hydrolyze $p$-nitrophenyl acetate to produce yellow product $p$-nitrophenol, which can be detected by the ultraviolet spectrum. In the presence of $\mathrm{Hg}^{2+}$, the production of $p$-nitrophenol is decreased.
Therefore, the $\mathrm{Hg}^{2+}$ concentration can be detected by measuring the ultraviolet absorption change of $p$-nitrophenol. Additionally, desorption of $\mathrm{Hg}^{2+}$ from carboxylesterase E2 occurs with variation of $\mathrm{pH}$ values and thus the surface-display system can be regenerated by regulating $\mathrm{pH}$ values in solution. In the meanwhile, the $\mathrm{Hg}^{2+}$ can be concentrated, avoiding the generation of hazardous byproducts.

\subsection{Verification of the surface-display system}

To verify that the carboxylesterase E2 was successfully displayed on the surface of E. coli Top10/pBATE2, SDS-PAGE and Western immunoblotting analysis were carried out. As shown in Fig. 2, the molecular mass of purified carboxylesterase E2 was about $26 \mathrm{kDa}$, which agreed with that reported in the previous study (Pesaresi et al., 2005). The carboxylesterase E2 was detected in the wholecell and outer membrane proteins of $E$. coli Top10/pBATE2 bacterial cells but not in its cytoplasmic proteins. The carboxylesterase E2 was not observed in any part of proteins from E. coli Top10 and Top10/pBAT1 bacterial cells. These results indicated that the carboxylesterase E2 was only located on the surface of E. coli Top10/ pBATE2 bacterial cells. To further verify that the carboxylesterase E2 had already been expressed on the out membrane of the E. coli Top10/pBATE2, E. coli Top10, Top10/pBAT1 and Top10/pBATE2 bacterial solutions were incubated with $0.5 \mathrm{mM} p$-nitrophenyl acetate at $25^{\circ} \mathrm{C}$ for $20 \mathrm{~min}$ and the ultraviolet absorption spectra of bacterial solutions were measured subsequently. As shown in Fig. S1, only the color of E. coli Top10/pBATE2 solution changed to yellow, because $p$-nitrophenyl acetate was hydrolyzed to $p$-nitrophenol by the carboxylesterase E2 on bacterial cell surface. The above-mentioned results illustrate that the carboxylesterase E2 has been successfully displayed on the outer membrane of E. coli Top10/ pBATE2 bacterial cells.

We further verified the plasmid stabilization of the E. coli Top10/

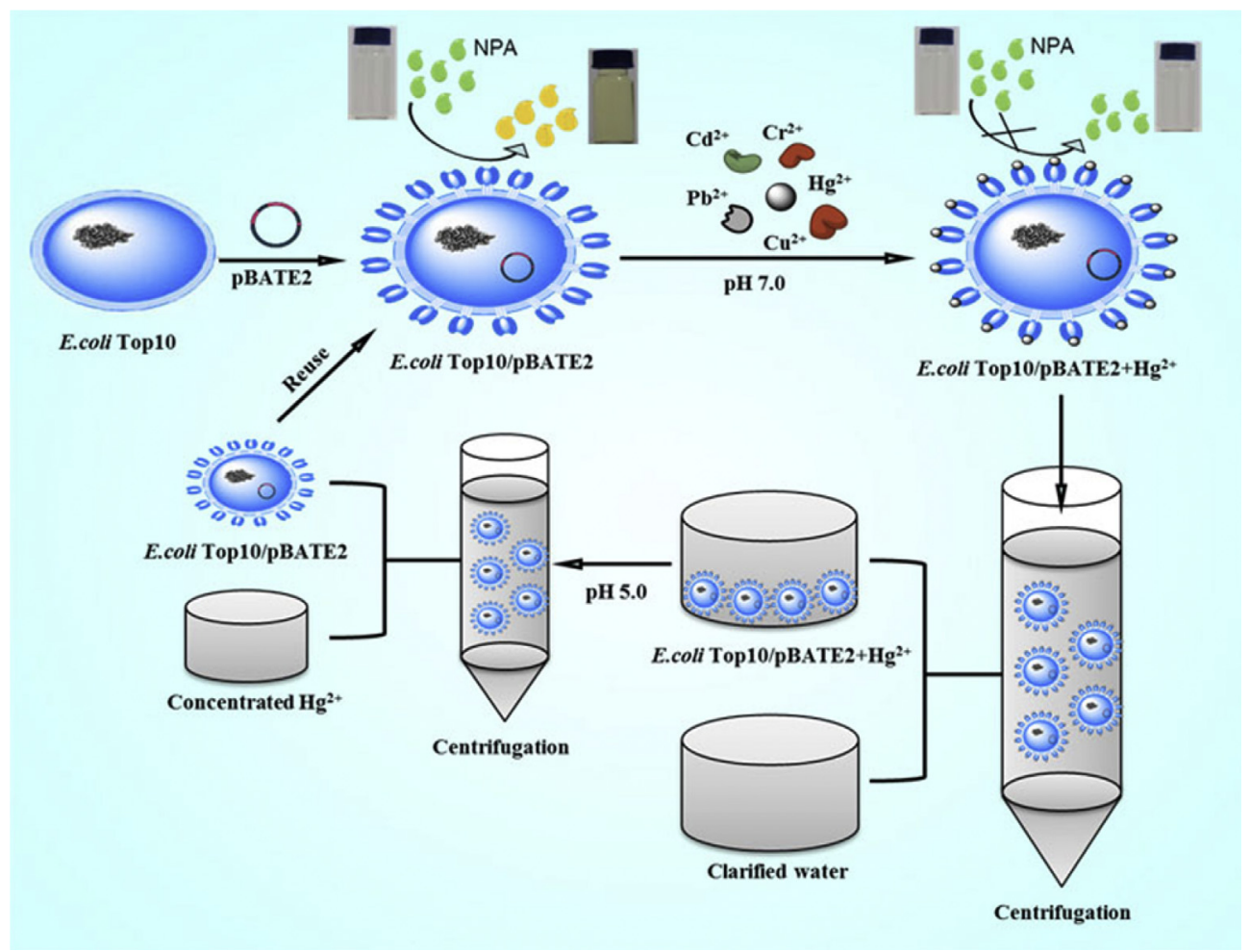

Fig. 1. Schematic illustration for the simultaneous remediation and detection of $\mathrm{Hg}^{2+}$ by carboxylesterase E2 surface-display system. 


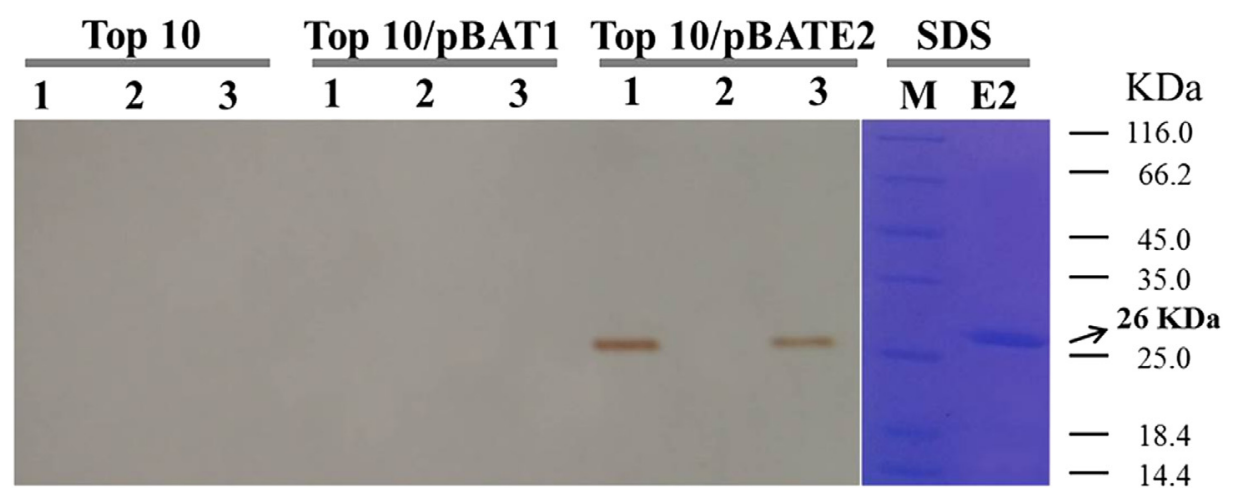

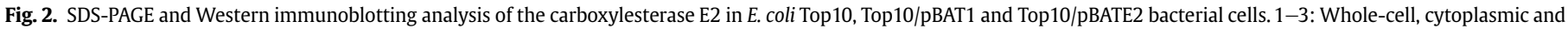
outer membrane proteins, respectively.

pBATE2 bacteria. As shown in Fig. S2, more than 95\% of the engineered bacterial cells carried the pBATE2 plasmid after 100 generations, indicating good plasmid stabilization of the E. coli Top10/ pBATE2 bacteria. We also investigated the survival rate of $E$. coli Top10/pBATE2 bacteria in pure water and mercury polluted water. As shown in Fig. S3, the survival rate did not change during $24 \mathrm{~h}$ in double distilled $\mathrm{H}_{2} \mathrm{O}, 0.1 \mathrm{mM} \mathrm{Hg}^{2+}$, or $1 \mathrm{mM} \mathrm{Hg}^{2+}$ solution, and slightly decreased in $10 \mathrm{mM} \mathrm{Hg}^{2+}$ solution, which means that the surface-displayed bacteria are able to be applied in bioremediation of mercury polluted water.

\subsection{Bioadsorption of mercury ion by the surface-display system}

To investigate the mercury adsorption capacity of the proposed surface display system, E. coli Top10, Top10/pBAT1 and Top10/ pBATE2 bacterial solutions were incubated with $0.1,0.5$ and $1 \mathrm{mM}$ $\mathrm{Hg}^{2+}$ at $25^{\circ} \mathrm{C}$ for $30 \mathrm{~min}$, respectively. As shown in Fig. 3a, the E. coli
Top10/pBATE2 bacteria were able to adsorb $\mathrm{Hg}^{2+}$ with a capacity of about $33.6 \mu \mathrm{mol} \mathrm{g}^{-1}$ cells in the $0.1 \mathrm{mM} \mathrm{Hg}^{2+}$ solution, which was higher than those of control groups $\left(21.6 \mu \mathrm{mol} \mathrm{g}{ }^{-1}\right.$ cells for $E$. coli Top10 and $19.6 \mu \mathrm{mol} \mathrm{g}^{-1}$ cells for $E$. coli Top10/pBAT1). The surfacedisplayed $E$. coli Top10/pBATE2 bacteria were able to adsorb $1 \mathrm{mM}$ $\mathrm{Hg}^{2+}$ with a capacity of about $297.2 \mu \mathrm{mol} \mathrm{g}^{-1}$ cells, which was about 3 -fold higher than those of control groups. The adsorption of $1 \mathrm{mM}$ $\mathrm{Hg}^{2+}$ by E. coli Top10/pBATE2 is a little higher than that by the traditional mercury-resistant strain Pseudomonas aeruginosa PU21 (about $170 \mu \mathrm{mol} \mathrm{g}^{-1}$ cells) (Chang and Hong, 1994). As shown in Fig. 3b, the effective adsorption rates of control groups decreased obviously from $50 \%$ in $0.1 \mathrm{mM} \mathrm{Hg}^{2+}$ solution to $25 \%$ in $1 \mathrm{mM} \mathrm{Hg}^{2+}$ solution. However, the effective adsorption rates of the surfacedisplayed E. coli Top10/pBATE2 bacteria maintained at approximately $80 \%$, which was much higher than those of control groups especially in high level of $\mathrm{Hg}^{2+}$ solution. The results indicate that the surface-displayed E. coli Top10/pBATE2 bacteria owned good (a)

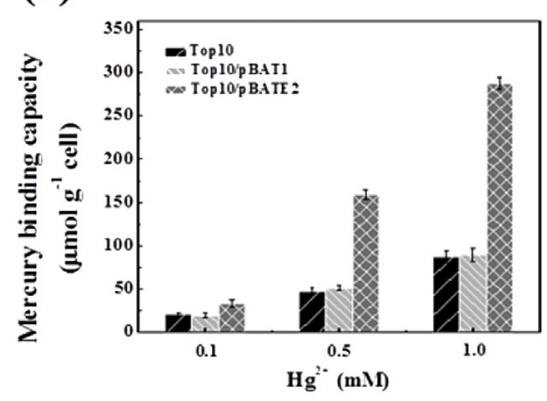

(d)

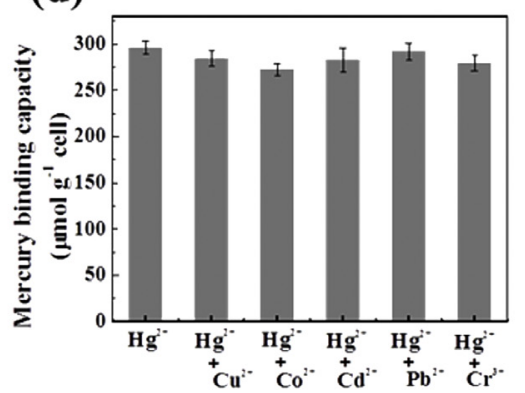

(b)

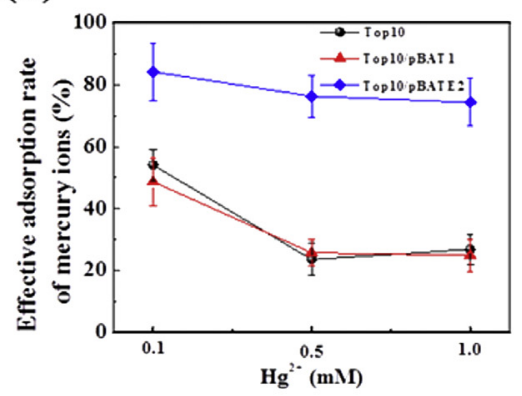

(c)

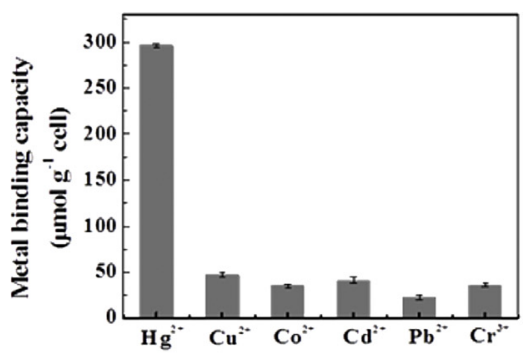

(e)

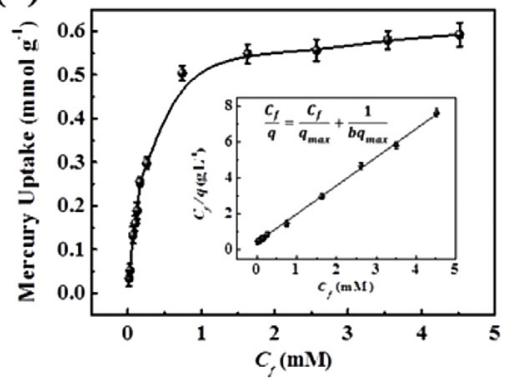

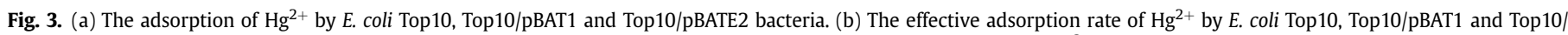

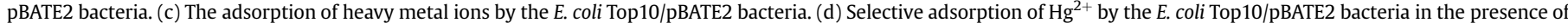

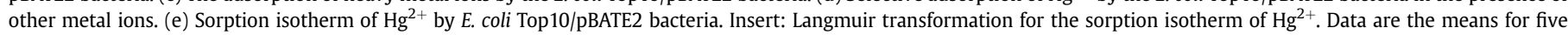
independent experiments. 
adsorption capacity and efficiency for $\mathrm{Hg}^{2+}$.

The selectivity of the $E$. coli Top10/pBATE2 bacteria to absorb $\mathrm{Hg}^{2+}$ was further examined. As shown in Fig. 3c, the adsorption capacity of $\mathrm{Hg}^{2+}$ by $E$. coli Top10/pBATE2 bacteria was much higher than those of other metal ions. Given mercury pollution was usually accompanied with other heavy metals, the influences of other metal ions including $\mathrm{Cu}^{2+}, \mathrm{Pb}^{2+}, \mathrm{Co}^{2+}, \mathrm{Cd}^{2+}$ and $\mathrm{Cr}^{3+}$ on the adsorption capacity of $\mathrm{Hg}^{2+}$ were explored, and the adsorption capacity of the E. coli Top10/pBATE2 to absorb $\mathrm{Hg}^{2+}$ was not affected in the presence of other metal ions (Fig. 3d).

The sorption isotherm of $\mathrm{Hg}^{2+}$ by the E. coli Top10/pBATE2 bacteria represents the equilibrium distribution of $\mathrm{Hg}^{2+}$ between bacteria and aqueous phase. $\mathrm{Hg}^{2+}$ uptake by surface-displayed E. coli bacteria increased with the rising of initial $\mathrm{Hg}^{2+}$ concentration (Fig. 3e) and the absorption data were fit to linear form of the Langmuir isotherm model:

$\frac{C_{f}}{q}=\frac{C_{f}}{q_{\max }}+\frac{1}{b q_{\max }}$

where $q$ is the metal uptake and $q_{\max }$ is the maximum adsorption capacity; $C_{f}$ is the final $\mathrm{Hg}^{2+}$ concentration at equilibrium; $b$ is the Langmuir constant, related to the adsorption energy. Our experimental data fit the Langmuir model with good linear correlation, suggesting that the adsorption of $\mathrm{Hg}^{2+}$ by the E. coli Top10/pBATE2 bacteria followed a physicochemical, equilibrated and saturatable mechanism. The maximum $\mathrm{Hg}^{2+}$ adsorption capacity was calculated about $612 \mu \mathrm{mol} \mathrm{g}^{-1}$ cells by using the Langmuir equation, which was comparable with those reported for traditional bioadsorption techniques for mercury remediation (about $900 \mu \mathrm{mol} \mathrm{g}^{-1}$ by mercury-resistant strain Pseudomonas aeruginosa PU21 (Chang and Hong, 1994) and $380 \mu \mathrm{mol} \mathrm{g}^{-1}$ by magnetically modified yeast cells (Yavuz et al., 2006)). All above results suggest that the developed surface display system exhibited excellent adsorption capacity and satisfied selectivity.

\subsection{Transmission electron microscopy analysis}

Considering the complexity of the microorganism's structure, there are various mechanisms for the remediation of metal ions, e.g., the metal ion reduction by cytophagy and cell surface sorption. As shown in our previous study (Zhang et al., 2012), the mercury ion can cross the bacteria cell membrane into the cytoplasm. This kind of biosorption is dependent on cells' metabolism and requires time to reduce the concentrations of metal ions. In contrast, the mercury adsorption on E. coli Top10/pBATE2 bacteria can be completed within $30 \mathrm{~min}$, which is not regulated by the abovementioned mechanism. For the cell surface sorption, the metal ions can be adsorbed on the outer membrane of microorganisms via physicochemical interaction with functional groups. In the current study, the carboxylesterase E2 was surface-displayed on the outer membrane of the $E$. coli bacteria to adsorb $\mathrm{Hg}^{2+}$. To investigate the adsorption mechanism of $\mathrm{Hg}^{2+}$ by our developed surface display system, the E. coli Top10 and Top10/pBATE2 bacteria cells were incubated with $1 \mathrm{mM} \mathrm{Hg}^{2+}$ at $25^{\circ} \mathrm{C}$ for $30 \mathrm{~min}$ and observed in turn by electronic microscopy. Black spots were clearly observed on the outer membrane of E. coli Top10/pBATE2 (Fig. 4b), but not on E. coli Top10 bacteria cells (Fig. 4a). To verify that the black spots were the accumulated $\mathrm{Hg}^{2+}$, the bacteria cells were lysed and the lysis solution was detected by AFS for $\mathrm{Hg}^{2+}$. As shown in Fig. 4c, the $\mathrm{Hg}^{2+}$ concentration in E. coli Top10/pBATE2 bacterial lysis solution was much higher than that in E. coli Top10 bacterial lysis solution $(p<0.01)$. These results further verified that the cell surface display of carboxylesterase E2 increased the adsorption capacity of the E. coli Top10 bacteria cells to $\mathrm{Hg}^{2+}$. (a)

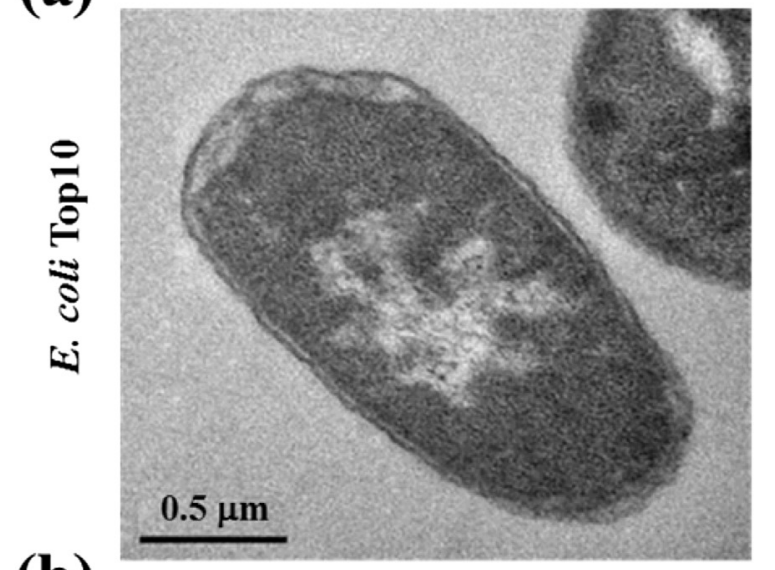

(b)

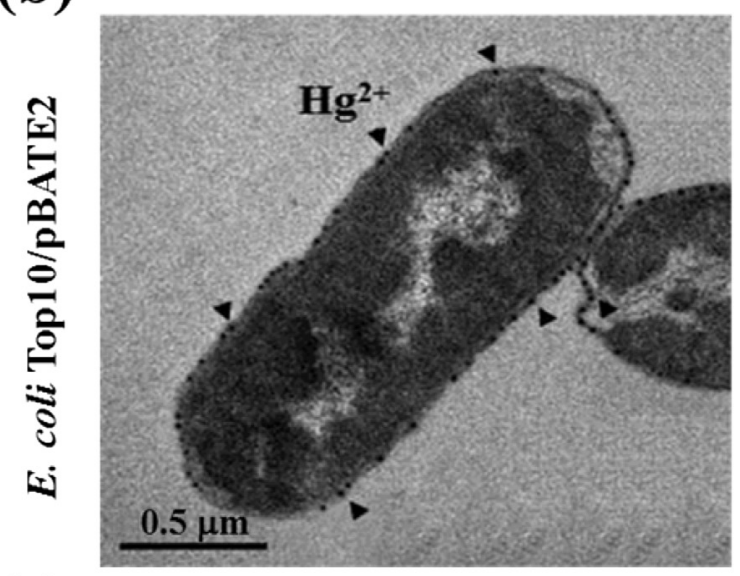

(c)

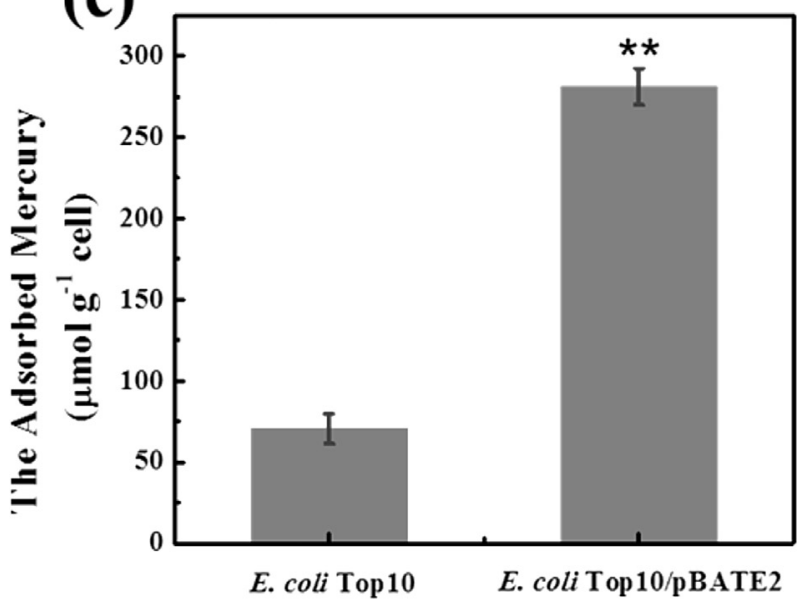

Fig. 4. Transmission electron micrographs of $E$. coli Top10 (a) and E. coli Top10/pBATE2 (b), after incubated with $1 \mathrm{mM} \mathrm{Hg}^{2+}$ for $30 \mathrm{~min}$. (c) The adsorbed mercury by E. coli Top10 and E. coli Top10/pBATE2 bacterial cells after incubated with $1 \mathrm{mM} \mathrm{Hg}^{2+}$ for $30 \mathrm{~min}^{* *}$ indicates a significant difference in the $\mathrm{Hg}^{2+}$ adsorption $(p<0.01 \mathrm{t}$-test) between groups E. coli Top10 and E. coli Top10/pBATE2. Data are the means for five independent experiments.

\subsection{The pH-regulated regeneration}

Next, we investigated the effects of $\mathrm{pH}$ values on the mercury adsorption performance of $E$. coli Top10/pBATE2 bacteria. The adsorption experiments of $1 \mathrm{mM} \mathrm{Hg}^{2+}$ by the $E$. coli Top10/pBATE2 
bacteria were performed in the Britton-Robinson (BR) solution under different $\mathrm{pH}$ values. As shown in Fig. S4a, the mercury binding capacity of the surface-displayed bacteria was highest at $\mathrm{pH} 7.0$ and decreased gradually to $36.8 \mu \mathrm{mol} \mathrm{g}^{-1}$ cells with $\mathrm{pH}$ value decreasing to 4.0. The free amine, hydroxyl and carboxyl groups are usually involved in the physic-chemical interaction of covalent binding of $\mathrm{Hg}^{2+}$ (Das et al., 2007). The nitrogen atom of amine group is able to bind to a proton or a metal ion by sharing the electron pair. Under neutral environment, the electrical attraction of the $\mathrm{Hg}^{2+}$ with the lone pairs of nitrogen atom is stronger than that of hydrogen ion, resulting in the binding of $\mathrm{Hg}^{2+}$ to nitrogen. At low $\mathrm{pH}$ values, the binding $\mathrm{Hg}^{2+}$ can be replaced by the hydrogen ion because of its high concentration. The accumulation of $\mathrm{Hg}^{2+}$ by hydroxyl and carboxyl groups is mainly due to the electrostatic interaction. With $\mathrm{pH}$ value increasing, the negatively charged carboxyl and hydroxyl groups are formed, which have strong affinity for $\mathrm{Hg}^{2+}$. The increased $\mathrm{pH}$ value makes the number of electrostatic interactions higher, which increases the adsorption of $\mathrm{Hg}^{2+}$ (Bulgariu et al., 2009). At $\mathrm{pH}$ value over 7.0, the adsorption capacity of $\mathrm{Hg}^{2+}$ decreases because $\mathrm{Hg}(\mathrm{OH})_{2}$ is the dominant species in solution. Therefore, the optimal accumulation of $\mathrm{Hg}^{2+}$ by $E$. coli Top10/pBATE2 bacteria was achieved at neutral $\mathrm{pH}$ value, suggesting a competitive mechanism for the chelation of protons and $\mathrm{Hg}^{2+}$ at the adsorption sites.

The regeneration ability of E. coli Top10/pBATE2 bacteria was further examined. As shown in Fig. S4b, only $3.5 \% \mathrm{Hg}^{2+}$ desorbed from E. coli Top10/pBATE2 bacteria at $\mathrm{pH} 7.0$, while almost $90.3 \%$ $\mathrm{Hg}^{2+}$ released from the bacteria at $\mathrm{pH} 5.0$. The results indicate that the accumulated $\mathrm{Hg}^{2+}$ could be released from the E. coli Top10/ pBATE2 bacteria by regulating $\mathrm{pH}$ values and the surface displayed system could be regenerated. The regenerated E. coli Top10/pBATE2 bacteria could be reused to adsorb $\mathrm{Hg}^{2+}$ for at least 5 times with almost no decrement in effective adsorption rate (Fig. S4c), which further indicates that the surface display system owned excellent regeneration ability.

Additionally, we investigated the influence of ionic strength on the adsorption of $\mathrm{Hg}^{2+}$ by the proposed surface-displayed system. As shown in Fig. S5, the adsorption of $\mathrm{Hg}^{2+}$ by E. coli Top10/pBATE2 bacteria decreased under high ionic strength condition, which agrees with that reported in a previous study (Ledin et al., 1997). The results indicated that the surface-displayed system seems not applicable to remediate mercury pollution in seawater.

\subsection{Detoxification of mercury in the culture of mung bean}

Mercury is a general blocker of aquaporins and can hinder the growth of plants, e.g., reduction in the speed of seed germination (Vander Willigen et al., 2006; Iqbal et al., 2014). Mercury stress results in the decrease of foliar chlorophyll content and causes damage to internal leaf structure (Dunagan et al., 2007). It is very important to investigate whether the surface-displayed bacteria is more potent for detoxification of mercury than common bacteria. As shown in Fig. $5 \mathrm{~A}(\mathrm{a}-\mathrm{c})$, the seedling growth of mung bean showed no difference among double distilled $\mathrm{H}_{2} \mathrm{O}$, double distilled $\mathrm{H}_{2} \mathrm{O}$ with E. coli Top 10 bacteria and double distilled $\mathrm{H}_{2} \mathrm{O}$ with $E$. coli Top10/pBATE2 bacteria treated groups. The results indicate that the presence of bacteria did not interfere the plant growth. The seedling growth of mung bean was significantly influenced in the presence of $10 \mathrm{mM} \mathrm{Hg}^{2+}$ alone or in combination with E. coli Top10 bacteria (Fig. 5A (d and e)). In comparison, a significant protective effect of $E$. coli Top10/pBATE2 bacteria was observed (Fig. 5A (f)). The seedling lengths of mung bean were measured in each group. The protection against mercury toxicity for the seedling growth of mung bean by E. coli Top10/pBATE2 bacteria is much better than that found for E. coli Top10 (Fig. 5B) $(p<0.01)$. This suggests that the surface-display of carboxylesterase E2 enhanced the mercury immobilization capacity of $E$. coli Top 10 bacteria and could confer better protective effect upon the seedling growth of mung bean in mercury polluted water.

\subsection{Biodetection of mercury ion by the surface display system}

Recently, enzyme-based biosensors have been wildly utilized in the detection of toxic compounds such as pesticides and heavy metals (Mulchandani et al., 2001; Chouteau et al., 2005; Syshchyk et al., 2015). To investigate the possibility of using the E. coli Top10/pBATE2 bacteria to detect $\mathrm{Hg}^{2+}$, the spectrum properties of $p$-nitrophenol hydrolyzed from $p$-nitrophenyl acetate by carboxylesterase E2 on the outer membrane of E. coli Top10/pBATE2 bacteria were measured in the absence/presence of $1 \mathrm{mM} \mathrm{Hg}^{2+}$, respectively. As shown in Fig. 6a, the absorbance of $p$-nitrophenol decreased obviously in the presence of $1 \mathrm{mM} \mathrm{Hg}^{2+}$, indicating that the activity of the carboxylesterase $\mathrm{E} 2$ was inhibited by $\mathrm{Hg}^{2+}$. The generation of the $p$-nitrophenol decreased gradually with the increase in the concentration of $\mathrm{Hg}^{2+}$. The inhibition of the $p$-nitrophenol generation can be directly recognized by naked eyes as well
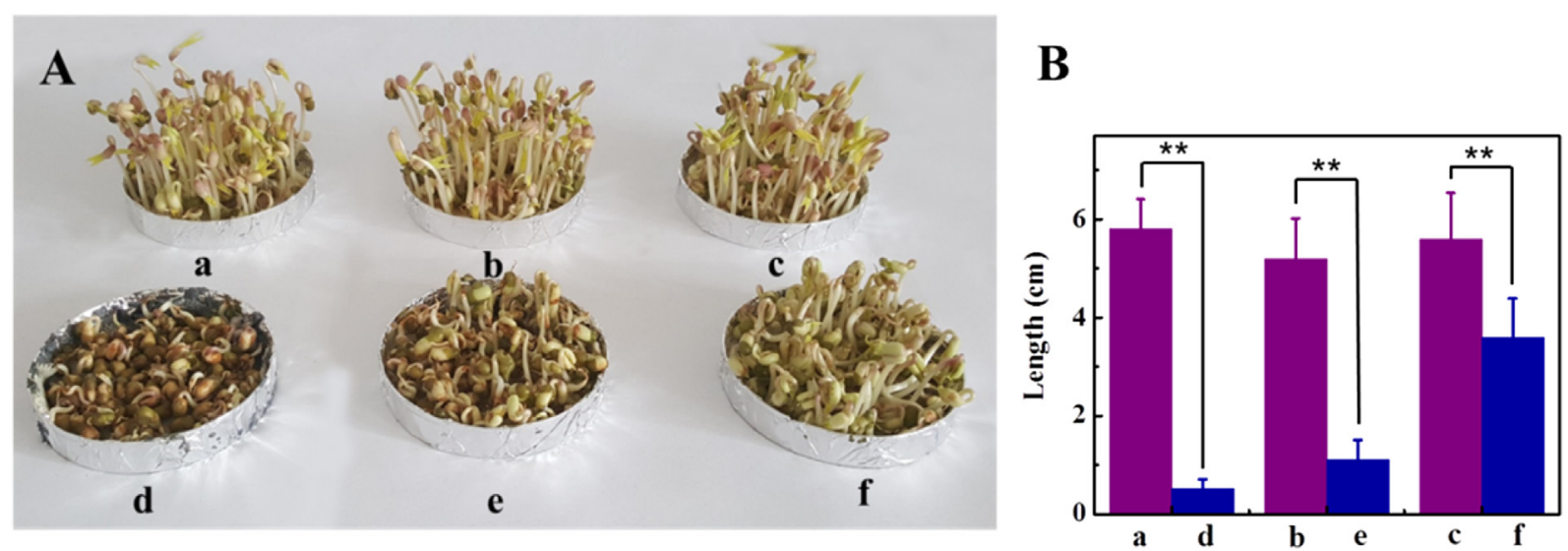

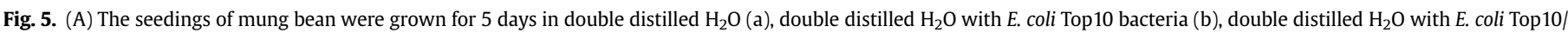

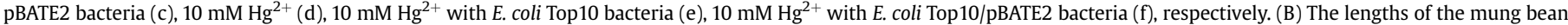

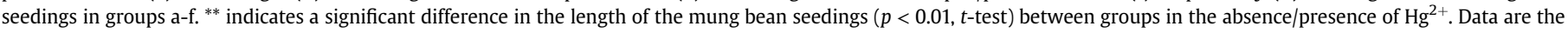
means for three independent experiments. 
(a)

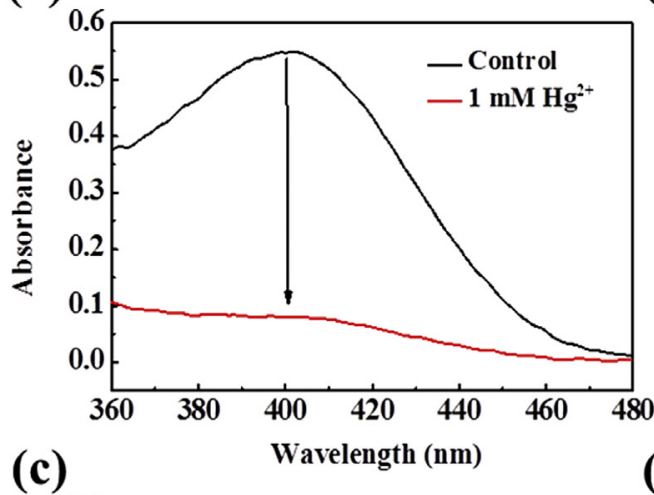

(c)

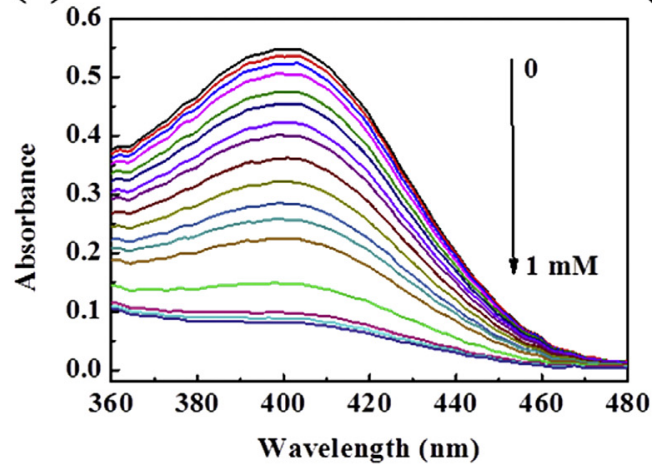

(b)

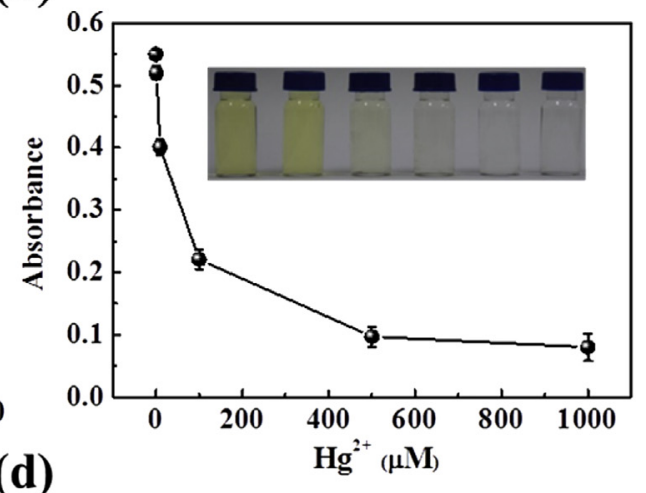

(d)

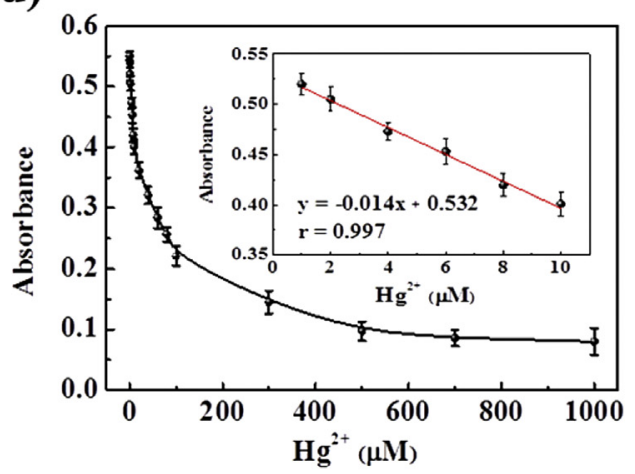

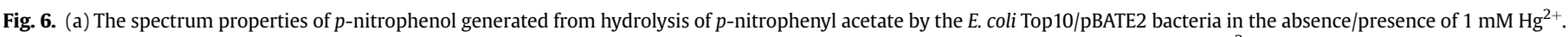

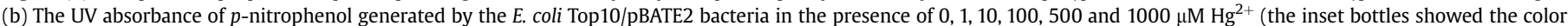

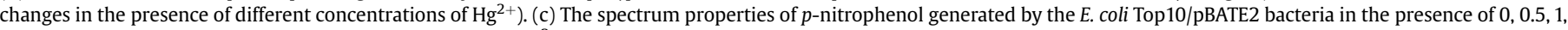

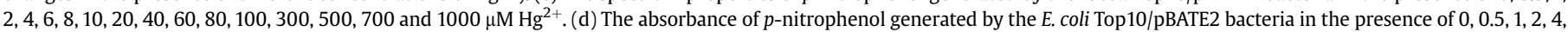

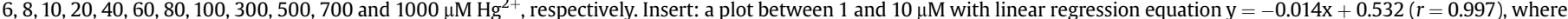

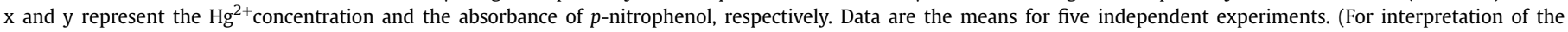
references to colour in this figure legend, the reader is referred to the web version of this article.)

as detected by the UV detector. As shown in Fig. $6 \mathrm{~b}, 10 \mu \mathrm{M} \mathrm{Hg}{ }^{2+}$ could be distinguished directly with naked eyes by utilizing our biosensor. We further optimized the reaction conditions to achieve the best detection of $\mathrm{Hg}^{2+}$. As shown in Fig. S6, the best performance of $E$. coli Top10/pBATE2 bacteria for the detection of $\mathrm{Hg}^{2+}$ was obtained: firstly incubated in $0.1 \mathrm{mM}$ PBS buffer at $\mathrm{pH} 7.0$ and $25{ }^{\circ} \mathrm{C}$ for $10 \mathrm{~min}$, then added with $0.5 \mathrm{mM} p$-nitrophenyl acetate and incubated at $25{ }^{\circ} \mathrm{C}$ for another $20 \mathrm{~min}$ to complete the detection.

To evaluate the selectivity of the developed biosensor towards $\mathrm{Hg}^{2+}$, the absorbance of $p$-nitrophenol generated by E. coli Top10/ pBATE2 bacteria were also detected in the presence of other metal ions. As shown in Fig. S7a, the absorbance of $p$-nitrophenol remained only $20 \%$ in the presence of $\mathrm{Hg}^{2+}$, while the absorbance did not show obvious decrease in the presence of other metal ions. This indicates that the activity of carboxylesterase E2 was only inhibited by $\mathrm{Hg}^{2+}$ and the detection of $\mathrm{Hg}^{2+}$ by our biosensor was not influenced by other metal ions (Fig. S7b). The results illustrate that the developed surface-display system showed an excellent selectivity and specificity toward $\mathrm{Hg}^{2+}$ over other metal ions.

To evaluate the sensitivity of the E. coli Top10/pBATE2 bacteria towards $\mathrm{Hg}^{2+}$, the concentrations of $\mathrm{Hg}^{2+}$ ranging from 0.5 to $1000 \mu \mathrm{M}$ were measured under the optimal conditions. As shown in Fig. $6 \mathrm{c}$ and $\mathrm{d}$, a good linearity in the range of $1-10.0 \mu \mathrm{M}$ was obtained $(\mathrm{r}=0.997)$ and the detection limit (LOD) for $\mathrm{Hg}^{2+}$ was $0.5 \mu \mathrm{M}$ (signal-to-noise $(\mathrm{S} / \mathrm{N})$ ratio $=3$ ), which was comparable with that reported for the previous biosensors $(2.5 \mu \mathrm{M}$ based on glucose oxidase (Malitesta and Guascito, 2005) and $0.5 \mu \mathrm{M}$ based on DNA oligonucleotides (Xu et al., 2009)). We further demonstrated the applicability of the $E$. coli Top10/pBATE2 bacteria in detection of $\mathrm{Hg}^{2+}$ in drinking, river and lake water samples. As shown in Table $\mathrm{S} 1$, the detected $\mathrm{Hg}^{2+}$ concentrations in spiked drinking, river and lake water samples by the developed biosensor agreed well with the results obtained by the traditional measurement by AFS. All above results indicated that the E. coli Top10/ pBATE2 bacteria could be applied as a simple and selective biosensor to detect $\mathrm{Hg}^{2+}$, which was credible and practically feasible for detecting $\mathrm{Hg}^{2+}$ in real water samples.

\section{Conclusions}

$\mathrm{Hg}^{2+}$ can exist in the environment for a very long time and cause serious environmental problems. The removal and the detection of toxic $\mathrm{Hg}^{2+}$ from the environment have become global issues and aroused increasing concerns. Therefore, a convenient and environmental friendly adsorption and detection method of $\mathrm{Hg}^{2+}$ is eagerly needed. Inspired by the bioelement carboxylesterase E2 from mercury-resistant strain Pseudomonas aeruginosa PA1, we have developed a surface display system to simultaneously adsorb and detect $\mathrm{Hg}^{2+}$. Our results have verified that the selective adsorption of $\mathrm{Hg}^{2+}$ is remarkably enhanced after the surface display of carboxylesterase E2 on the outer membrane of the E. coli bacteria. In the meanwhile, the activity of surface-displayed carboxylesterase $\mathrm{E} 2$ can be inhibited by the binding $\mathrm{Hg}^{2+}$, which has been utilized to selectively detect $\mathrm{Hg}^{2+}$ in spiked drinking, river and lake water samples. Therefore, the developed surface display system can be utilized as a simple method for the simultaneous remediation and detection of $\mathrm{Hg}^{2+}$. Additionally, our experiment 
has explored a new design strategy for application of functional enzyme in simultaneous remediation and detection of heavy metal pollution.

\section{Acknowledgments}

This work was financially supported by the National Natural Science Foundation of China (No. 21575159, 21522706, 21275158), the Strategic Priority Research Program of the Chinese Academy of Sciences (XDA11020702), and the Thousand Young Talents Program of China.

\section{Appendix A. Supplementary data}

Supplementary data related to this article can be found at http:// dx.doi.org/10.1016/j.watres.2016.07.053.

\section{References}

Bakir, F., Damluji, S.F., Amin-Zaki, L., Murtadha, M., Khalidi, A., Al-Rawi, N.Y., Tikriti, S., Biondo, R., da Silva, F.A., Vicente, E.J., Souza Sarkis, J.E., Schenberg, A.C.G., 2012. Synthetic phytochelatin surface display in Cupriavidus metallidurans $\mathrm{CH} 34$ for enhanced metals bioremediation. Environ. Sci. Technol. 46, 8325-8332.

Bulgariu, D., Bulgariu, L., 2012. Equilibrium and kinetics studies of heavy metal ions biosorption on green algae waste biomass. Bioresour. Technol. 103, 489-493.

Bulgariu, L., Ratoi, M., Bulgariu, D., Macoveanu, M., 2009. Adsorption potential of mercury (II) from aqueous solutions onto Romanian peat moss. J. Environ. Sci. Heal. A 44, 700-706.

Cardenas, A., Koestler, D.C., Houseman, E.A., Jackson, B.P., Kile, M.L., Karagas, M.R., Marsit, C.J., 2015. Differential DNA methylation in umbilical cord blood of infants exposed to mercury and arsenic in utero. Epigenetics 10, 508-515.

Chang, J.S., Hong, J., 1994. Biosorption of mercury by the inactivated cells of Pseudomonas aeruginosa PU21 (Rip64). Biotechnol. Bioeng. 44, 999-1006.

Cheng, S., 2003. Heavy metal pollution in China: origin, pattern and control. Environ. Sci. Pollut. R. 10, 192-198.

Chouteau, C., Dzyadevych, S., Durrieu, C., Chovelon, J.M., 2005. A bi-enzymatic whole cell conductometric biosensor for heavy metal ions and pesticides detection in water samples. Biosens. Bioelectron. 21, 273-281.

Dahahir, H.I., Clarkson, T.W., Smith, J.C., Doherty, R.A., 1973. Methylmercury poisoning in Iraq. Science 181, 230-241.

Das, S.K., Das, A.R., Guha, A.K., 2007. A study on the adsorption mechanism of mercury on Aspergillus versicolor biomass. Environ. Sci. Technol. 41, $8281-8287$.

Dunagan, S.C., Gilmore, M.S., Varekamp, J.C., 2007. Effects of mercury on visible/ near-infrared reflectance spectra of mustard spinach plants (Brassica rapa P.). Environ. Pollut. 148, 301-311.

Harada, M., 1995. Minamata disease: methylmercury poisoning in Japan caused by environmental pollution. Crit. Rev. Toxicol. 25, 1-24.

Houston, M.C., 2011. Role of mercury toxicity in hypertension, cardiovascular disease, and stroke. J. Clin. Hypertens. 13, 621-627.

Iqbal, M.Z., Shafiq, M., Athar, M., 2014. Phytotoxic effects of mercury on seed germination and seedling growth of Albizia lebbeck (L.) Benth. (Leguminosae). Adv. Environ. Res. 3, 207-216.

Järup, L., 2003. Hazards of heavy metal contamination. Brit. Med. Bull. 68, 167-182.

Jiang, G.B., Shi, J.B., Feng, X.B., 2006. Mercury pollution in China. Environ. Sci. Technol. 40, 3672-3678.

Jurng, J., Lee, T.G., Lee, G.W., Lee, S.J., Kim, B.H., Seier, J., 2002. Mercury removal from incineration flue gas by organic and inorganic adsorbents. Chemosphere 47, 907-913.

Ledin, M., Pedersen, K., Allard, B., 1997. Effects of pH and ionic strength on the adsorption of Cs, Sr, Eu, Zn, Cd and Hg by Pseudomonas putida. Water Air Soil Pollut. 93, 367-381.

Lee, S.Y., Choi, J.H., Xu, Z., 2003. Microbial cell-surface display. Trends Biotechnol. 21, 45-52.

Liu, S., Hou, J.H., Sun, L., 2005. Identification, characterization, and molecular application of a virulence-associated autotransporter from a pathogenic Pseudomonas fluorescens strain. Appl. Environ. Microbiol. 75, 4333-4340.

Liu, R., Yang, C., Xu, Y., Xu, P., Jiang, H., Qiao, C., 2013. Development of a whole-cell biocatalyst/biosensor by display of multiple heterologous proteins on the
Escherichia coli cell surface for the detoxification and detection of organophosphates. J. Agr. Food Chem. 61, 7810-7816.

Lund, B.O., Miller, D.M., Woods, J.S., 1991. Biochem. Pharmacol. 42, 181-187.

Malitesta, C., Guascito, M.R., 2005. Heavy metal determination by biosensors based on enzyme immobilised by electropolymerisation. Biosens. Bioelectron. 20, $1643-1647$.

Meyer, J.N., Leung, M.C., Rooney, J.P., Sendoel, A., Hengartner, M.O., Kisby, G.E. Bess, A.S., 2013. Mitochondria as a target of environmental toxicants. Toxicol. Sci. 134, 1-17.

Moreno, F., Garcia-Barrera, T., Gomez-Ariza, J.L., 2010. Simultaneous analysis of mercury and selenium species including chiral forms of selenomethionine in human urine and serum by HPLC column-switching coupled to ICP-MS. Analyst 135, 2700-2705.

Mudhoo, A., Garg, V.K., Wang, S., 2012. Removal of heavy metals by biosorption. Environ. Chem. Lett. 10, 109-117.

Mulchandani, P., Chen, W., Mulchandani, A., 2001. Flow injection amperometric enzyme biosensor for direct determination of organophosphate nerve agents. Environ. Sci. Technol. 35, 2562-2565.

Pal, M., Ghosh, M., 2012. Studies on comparative efficacy of $\alpha$-linolenic acid and $\alpha$ eleostearic acid on prevention of organic mercury-induced oxidative stress in kidney and liver of rat. Food Chem. Toxicol. 50, 1066-1072.

Park, J.D., Zheng, W., 2012. Human exposure and health effects of inorganic and elemental mercury. J. Prev. Med. Public Health 45, 344-352.

Pesaresi, A., Devescovi, G., Lamba, D., Venturi, V., Degrassi, G., 2005. Isolation, characterization, and heterologous expression of a carboxylesterase of Pseudomonas aeruginosa PA01. Curr. Microb. 50, 102-109.

Rodgers, J.S., Hocker, J.R., Hanas, R.J., Nwosu, E.C., Hanas, J.S., 2001. Mercuric ion inhibition of eukaryotic transcription factor binding to DNA. Biochem. Pharmacol. 61, 1543-1550.

Saleem, M., Brim, H., Hussain, S., Arshad, M., Leigh, M.B., 2008. Perspectives on microbial cell surface display in bioremediation. Biotechnol. Adv. 26, 151-161.

Shafawi, A., Ebdon, L., Foulkes, M., Stockwell, P., Corns, W., 2000. Preliminary evaluation of adsorbent-based mercury removal systems for gas condensate. Anal. Chim. Acta 415, 21-32.

Sheng, G.P., Xu, J., Luo, H.W., Li, W.W., Li, W.H., Yu, H.Q., Xie, Z., Wei, S.Q., Hu, F.C., 2013. Thermodynamic analysis on the binding of heavy metals onto extracellular polymeric substances (EPS) of activated sludge. Water Res. 47, 607-614.

Syshchyk, O., Skryshevsky, V.A., Soldatkin, O.O., Soldatkin, A.P., 2015. Enzyme biosensor systems based on porous silicon photoluminescence for detection of glucose, urea and heavy metals. Biosens. Bioelectron. 66, 89-94.

Vander Willigen, C., Postaire, O., Tournaire-Roux, C., Boursiac, Y., Maurel, C., 2006. Expression and inhibition of aquaporins in germinating Arabidopsis seeds Plant Cell Physiol. 47, 1241-1250.

Wei, W., Liu, X., Sun, P., Wang, X., Zhu, H., Hong, M., Mao, Z.W., Zhao, J., 2014. Simple whole-cell biodetection and bioremediation of heavy metals based on an engineered lead-specific operon. Environ. Sci. Technol. 48, 3363-3371.

Wu, C.H., Mulchandani, A., Chen, W., 2008. Versatile microbial surface-display for environmental remediation and biofuels production. Trends Microbiol. 16, $181-188$.

Xu, X., Wang, J., Jiao, K., Yang, X., 2009. Colorimetric detection of mercury ion $\left(\mathrm{Hg}^{2+}\right)$ based on DNA oligonucleotides and unmodified gold nanoparticles sensing system with a tunable detection range. Biosens. Bioelectron. 24, 3153-3158.

Yavuz, H., Denizli, A., Güngüneş, H., Safarikova, M., Safarik, I., 2006. Biosorption of mercury on magnetically modified yeast cells. Sep. Purif. Technol. 52, 253-260.

Yin, K., Zhang, W., Chen, L., 2014. Pyoverdine secreted by Pseudomonas aeruginos as a biological recognition element for the fluorescent detection of furazolidone. Biosens. Bioelectron. 51, 90-96.

Zalups, R.K., 2000. Molecular interactions with mercury in the kidney. Pharmacol. Rev. 52, 113-144.

Zhang, W.B., Su, Z.F., Chu, X.F., Yang, X.A., 2010. Evaluation of a new electrolytic cold vapor generation system for mercury determination by AFS. Talanta 80, 2106-2112.

Zhang, W., Chen, L., Liu, D., 2012. Characterization of a marine-isolated mercuryresistant Pseudomonas putida strain SP1 and its potential application in marine mercury reduction. Appl. Microb. Biot. 93, 1305-1314.

Zhang, W., Yin, K., Li, B., Chen, L., 2013. A glutathione S-transferase from Proteus mirabilis involved in heavy metal resistance and its potential application in removal of $\mathrm{Hg}^{2+}$. J. Hazard. Mater 261, 646-652.

Zhang, S., Li, J., Zeng, M., Xu, J., Wang, X., Hu, W., 2014. Polymer nanodots of graphitic carbon nitride as effective fluorescent probes for the detection of $\mathrm{Fe}^{3+}$ and $\mathrm{Cu}^{2+}$ ions. Nanoscale 6, 4157-4162.

Zhao, G., Li, J., Ren, X., Chen, C., Wang, X., 2011. Few-layered graphene oxide nanosheets as superior sorbents for heavy metal ion pollution management. Environ. Sci. Technol. 45, 10454-10462. 